\title{
Proceeding
}

Supplementary Issue: Winter Conferences of Sports Science. Costa Blanca Sports Science Events, 22-23 March 2021. Alicante, Spain.

\section{The human behavioral and practical model of 'at- risk teacher training' at Kazan Federal University: Sports and educational environment}

\author{
LEYSAN R. KAYUMOVA , VENERA G. ZAKIROVA \\ Institute of Psychology and Education, Kazan (Volga region) Federal University, Russian Federation
}

\begin{abstract}
Purpose of the Study: Risks have become an integral part of the modern world. Elevated risk levels resulted from an accelerated pace that modern society has developed at, extreme degree of digitalization and informatization of human life. The system of education is therefore challenged by additional tasks to educate future generations for situations of risk. In view of this, this research aims to find and justify a suitable measure to evaluate the effectiveness of the 'at-risk teacher training' model. The purpose of this empiric study is to examine whether the 'at-risk teacher training' model is efficient. Methodology: Beta-testing of the model of 'at-risk teacher training' has been run in the Institute of psychology and education at Kazan Federal University since 2013. The research tool used is the questionnaire on coping strategies developed by Heim. Main Findings: According to Russian researchers studying risks, a teacher's willingness to work in risk situations is defined as the noxological competence. Noxological competence includes situational, motivational, cognitive, active, analytical, and reflexive components. Thus, the performance evaluation of the 'at-risk teacher training' model equals assessment of the noxological competence development of teachers. However, there is no single measure that can assess all components of the noxological competencies. According to this view, the authors designed the model of 'at-risk teacher training' building on the importance of action competencies in situations of risk which are essential for a professional teaching career in the modern world. Applications of this study: The research helped to identify student teachers' motivation for communication, behaviour patterns in conflict situations, ability to understand non-verbal communication cues and gestures, which are referred to as essential professional teaching competencies needed to resolve and manage conflict situations. Novelty/Originality of this study: The authors suggested a possible suitable measure to evaluate the effectiveness of the 'at-risk teacher training' model.

Keywords: Human behavioural; Practical model; Teacher's noxological competences; Risk-oriented teacher training.
\end{abstract}

Cite this article as:

Kayumova, L.R., \& Zakirova, V.G. (2021). The human behavioral and practical model of 'at-risk teacher training' at Kazan Federal University: Sports and educational environment. Journal of Human Sport and Exercise, 16(3proc), S1151-S1161. https://doi.org/10.14198/jhse.2021.16.Proc3.31

Corresponding author. Institute of Psychology and Education, Kazan (Volga region) Federal University, Russian Federation.

E-mail: k lu.90@yahoo.com

Abstract submitted to: Winter Conferences of Sports Science. Costa Blanca Sports Science Events, 22-23 March 2021. Alicante, Spain.

JOURNAL OF HUMAN SPORT \& EXERCISE ISSN 1988-5202.

(c) Faculty of Education. University of Alicante.

doi:10.14198/jhse.2021.16.Proc3.31 


\section{INTRODUCTION}

Risks have become an integral part of modern world. Elevated risk levels resulted from an accelerated pace that the modern society has developed at, extreme degree of digitalization and informatization of human life. The system of education is therefore challenged by additional tasks to educate future generations for situations of risk (Makarova et al., 2019; Razumovskaya et al., 2019; Shinkevich et al., 2020). Kennedy, Latham \& Jacinto (2016) underlined that one of the main requirements to teachers is the ability to work in situations of risk. Such educational tasks are impossible without the development of action competencies in situations of risk among teachers. According to Russian researchers studying risks, a teacher's willingness to work in risk situations is defined as the noxological competence. S.V. Belov, E.N. Simakova (2013) defined noxology as an independent area of knowledge about risks and ways to prevent them. However, the study of noxology as a basic professional module is available only at technical courses (Bayanova et al., 2019; Piralova et al., 2020). Teacher education curricula do not include modules on risk-based training.

We designed the model of 'at-risk teacher training' building on the importance of action competencies in situations of risk which are essential for a professional teaching career in the modern world. Beta-testing of the model of 'at-risk teacher training' has been run in the Institute of psychology and education at Kazan Federal University since 2013.

The purpose of this empiric research is to examine whether the 'at-risk teacher training' model is efficient. The research tool used is the questionnaire on coping strategies developed by E. Heim (1988).

\section{Literature review}

The research builds on the theoretical framework of the life safety culture and the noxological competence in the university system (Abramova, 1996; Devisilov, 2011; Sabinina, 2011; Mikhailova, 2010; Prichinin, 2014; Kutuev et al., 2016; Avdeev et al., 2019; Gimaliev et al., 2020). V.A. Devisilov (2011) was one of the first scholars who emphasized the problem of risks in professional activities. He studied risks as real or potential threats to an employee's life and health.

Pedagogical riskology is a relatively new field of pedagogy. I. Abramova (1996) is known as the founder of the theory of pedagogical riskology in Russia. I. Abramova (1996) focuses on the multidimensional nature of the concept of 'risk' and defines the concept of reasonable pedagogical risk as one of the conditions for the development of an activity approach in teacher training. The scholar's theory was reflected in the works by E. Mikhailova (2010), N. Sabinina (2011), A. Prichinin (2014) who specified and broadened the classification of risks in an educational environment. In addition, it is essential to pinpoint the role of the state in security assurance.

Pedagogical riskology studies the social nature of risks and dangers. Also, it includes studies on the nature of conflict, ways of conflict resolving in social psychology (Aronson, Wilson \& Akert, 2015), research into the impact of conflict situations on the effectiveness of teamwork and intergroup relations (Smith et al., 2018; Orekhovskaya et al., 2019), studies on the mental state of people experiencing conflict situations and their patterns of behaviour (Havermans, Vanassche \& Matthijs, 2017).

In terms of the methodology, the 'at-risk teacher education' model builds on the research of simulation gaming and non-gaming technologies in teaching. The use of simulation technologies in education was studied by R. Duke (1983), Y. Middlewick, T.J. Kettle and J. J. Wilson (2012), A.P. Panfilova (2006), I.V. Plaksina (2004). 


\section{RESEARCH METHODOLOGY}

The study was carried out in three stages. At the first stage, we designed the model of 'at-risk teacher education' and devised its content (Prokofieva et al., 2018; Khairullina et al., 2020). At the second stage, the model was tested. At the third stage, the effectiveness of the model was evaluated. The thirst two stages were described in detail in our previous articles (Kayumova \& Zakirova, 2016; Kong, Kayumova \& Zakirova, 2017) which is why this article focuses on the third stage of the research.

According to Russian researchers studying risks, a teacher's willingness to work in risk situations is defined as the noxological competence. The noxological competence includes situational, motivational, cognitive, active, analytical, and reflexive components. Thus, the performance evaluation of the 'at-risk teacher training' model equals assessment of the noxological competence development of teachers. However, there is no single measure that can assess all components of the noxological competencies. In view of this, this research aims to find and justify a suitable measure to evaluate the effectiveness of the 'at-risk teacher training' model. Due to the complexity and multidimensional nature of the noxological competencies, the assessment of the competence development should be conducted taken as a whole (Zyubina et al., 2019; Podymov et al., 2019). In this article, we elaborate on the assessment of the noxological competence development according to its three components: active, situational, cognitive. The experimental design used in this study is the pretest-post-test control and experimental group design. The research tool employed in this study is the questionnaire on coping strategies developed by E. Heim (1988).

E. Heim's (1988) questionnaire on coping strategies allows to identify individual behaviour patterns, both unproductive behaviour patterns and personality resources, in conflict situations. In terms of the noxological competence development, this method can pinpoint student teachers' (relatively frequent) stress coping strategies that are already developed and predict how these strategies will manifest in risk situations in professional life.

The research tool consists of three sections corresponding to three groups of coping strategies (cognitive, emotional, behavioural). Each participant is asked to choose one statement from each section. If a participant selects a specific item as the most suitable for oneself, it is assumed that a relevant coping strategy will be typical for that participant. Qualitatively meaningful data analysis was employed to interpret responses. Each statement corresponds to a certain coping strategy. Behaviour patterns of each section can be adaptive, nonadaptive and relatively adaptive (productive, non-productive and relatively productive). Coding of the coping strategies was done according to the statements: P - productive coping strategy (helps to quickly and successfully cope with stress); $\mathrm{O}$ - relatively productive coping strategy (helps in some not very significant situations involving little stress); $\mathrm{N}$ - non-productive coping strategy (does not eliminate stress, on the contrary, contributes to its strengthening). Correspondence of coping strategies and criteria used for measuring the levels of noxological competence development of student teachers is presented in Table 1. According to Table 1, a productive coping strategy corresponds to a high level (a confident application of the competence in unconventional situations). A relatively productive coping strategy corresponds to an average level (basic development of the competence). A non-productive coping strategy corresponds to a low level of development. 
Table1. Correspondence of coping strategies and criteria used for measuring the levels of noxological competence development of student teachers.

\begin{tabular}{|c|c|c|c|}
\hline \multirow{2}{*}{$\begin{array}{l}\text { Components of } \\
\text { noxologic } \\
\text { competence }\end{array}$} & \multicolumn{3}{|l|}{ Coping Strategies } \\
\hline & Non-productive & $\begin{array}{l}\text { Relatively } \\
\text { productive }\end{array}$ & Productive \\
\hline \multicolumn{4}{|c|}{ Cognitive coping strategies } \\
\hline $\begin{array}{l}\text { Criteria used to } \\
\text { measure the levels } \\
\text { of the cognitive } \\
\text { component } \\
\text { development }\end{array}$ & $\begin{array}{l}\text { Ability to identify, distinguish } \\
\text { a previously familiar object, } \\
\text { phenomenon, information } \\
\text { about risks according to } \\
\text { basic theoretical principles } \\
\text { of ensuring safety in the } \\
\text { education system } \\
\text { ('knowledge - introduction' } \\
\text { according to V.P. Bespalko } \\
\text { (1996)). }\end{array}$ & $\begin{array}{l}\text { Ability to reproduce } \\
\text { previously learned } \\
\text { information about } \\
\text { risks according to } \\
\text { basic theoretical } \\
\text { principles of ensuring } \\
\text { safety in the } \\
\text { education system } \\
\text { ('knowledge - copies' } \\
\text { according to V.P. } \\
\text { Bespalko (1996)). }\end{array}$ & $\begin{array}{l}\text { Ability to apply acquired knowledge } \\
\text { in practical activities to ensure safety } \\
\text { in the education system ('knowledge } \\
\text { - skills' according to V.P. Bespalko } \\
(1996) \text { ). }\end{array}$ \\
\hline \multicolumn{4}{|c|}{ Emotional coping strategies } \\
\hline $\begin{array}{l}\text { Criteria used to } \\
\text { measure the levels } \\
\text { of the motivational } \\
\text { component } \\
\text { development }\end{array}$ & $\begin{array}{l}\text { Negative attitude to a future } \\
\text { profession; } \\
\text { Denial of risks associated } \\
\text { with professional teaching. }\end{array}$ & $\begin{array}{l}\text { Indifference to risk } \\
\text { situations in an } \\
\text { educational } \\
\text { environment; } \\
\text { Desire to minimize } \\
\text { any manifestations of } \\
\text { situations of } \\
\text { uncertainty and risk. }\end{array}$ & $\begin{array}{l}\text { Ability to identify the developing } \\
\text { potential of risk situations in } \\
\text { education; } \\
\text { Acceptance of risk as a condition for } \\
\text { the development of an individual. }\end{array}$ \\
\hline \multicolumn{4}{|c|}{ Behavioural coping strategies } \\
\hline $\begin{array}{l}\text { Criteria used to } \\
\text { measure the levels } \\
\text { of the active } \\
\text { component } \\
\text { development }\end{array}$ & $\begin{array}{l}\text { Avoidance, rejection of risk } \\
\text { situations. }\end{array}$ & $\begin{array}{l}\text { Tendency not to take } \\
\text { an active position in } \\
\text { risk situations; } \\
\text { Application of existing } \\
\text { algorithms of actions } \\
\text { in risk situations. }\end{array}$ & $\begin{array}{l}\text { Understanding of the organizational } \\
\text { structure of teaching and learning in } \\
\text { situations of risk' } \\
\text { Ability to predict and plan } \\
\text { professional teaching activities in } \\
\text { situations of risk }\end{array}$ \\
\hline $\begin{array}{l}\text { Criteria used to } \\
\text { measure the levels } \\
\text { of the situational } \\
\text { component } \\
\text { development }\end{array}$ & $\begin{array}{l}\text { Non-acceptance of risk } \\
\text { situations in education, } \\
\text { assessment of conflict } \\
\text { situations is extremely } \\
\text { negative; } \\
\text { Tendency to avoid any } \\
\text { manifestations of risk } \\
\text { situations or creation of } \\
\text { conflicts without analysing } \\
\text { possible consequences; } \\
\text { Lack of managerial skills in } \\
\text { the field of education in } \\
\text { situations of risk or conflict in } \\
\text { education settings. }\end{array}$ & $\begin{array}{l}\text { Ability to identify and } \\
\text { predict potential risks } \\
\text { of educational } \\
\text { environment; } \\
\text { Ability to assess } \\
\text { possible } \\
\text { consequences of risk } \\
\text { situations } \\
\text { education; } \\
\text { Acquaintance with } \\
\text { teaching and learning } \\
\text { theories in situations } \\
\text { of risk or in situations } \\
\text { of possible conflicts in } \\
\text { education. }\end{array}$ & $\begin{array}{l}\text { Ability to identify and predict } \\
\text { potential risks of educational } \\
\text { environment; } \\
\text { Ability to assess possible } \\
\text { consequences of risk situations in } \\
\text { education; } \\
\text { Intuitive identification of possible } \\
\text { reasons behind the development of } \\
\text { risk situations and conflicts in } \\
\text { education; } \\
\text { Ability to manage the educational } \\
\text { process in situations of risk or in } \\
\text { situations of possible conflicts in } \\
\text { education. }\end{array}$ \\
\hline
\end{tabular}

Statistical data analysis was performed with the use of Fisher's permutation test. 


\section{RESULTS}

The research experiment was run at the Institute of Psychology and Education, Volga Centre for Advanced Studies and Professional Retraining of Teachers, and the Institute of Philology and Intercultural Communication of Kazan Federal University. The research comprised of 14 participants. The experimental group consisted of 62 participants, and control group comprised 152 participants.

Results were interpreted in two stages:

1. Comparative analysis of the research results on the effectiveness of the 'at-risk' model of teacher training (experimental and control groups). Research results allow to elaborate on the effectiveness of the 'at-risk' model of teacher training in the development of personality qualities.

2. Fisher's permutation test (F-test) to determine what proportion of observations in a given sample has the necessary effect.

\section{Ascertaining experiment results}

The majority of the participants chose to use relatively productive coping strategies in situations of risk (Figure 1):

- Cognitive coping strategies (control group) -65,3\% (89 participants);

- Cognitive coping strategies (experimental group) - 43,3\% (27 participants);

- Emotional coping strategies (control group) - 40\% (61 participants);

- Emotional coping strategies (experimental group) - 58,4\% (37 participants);

- Behavioural coping strategies (control group) -64,5\% (97 participants);

- Behavioural coping strategies (experimental group) - 59,5\% (37 participants).

Effectiveness of these behaviour patterns depends on a specific situation. The use of productive behaviour patterns scored a lower percentage (compared with relatively productive behaviour patterns):

- Cognitive coping strategies (control group) - 18,7\% (29 participants);

- Cognitive coping strategies (experimental group) - 35,7\% (22 participants);

- Emotional coping strategies (control group) - 26,7\% (41 participants);

- Emotional coping strategies (experimental group) - 21,6\% (13 participants);

- Behavioural coping strategies (control group) - 11,3\% (17 participants);

- Behavioural coping strategies (experimental group) - 18,4\% (11 participants).

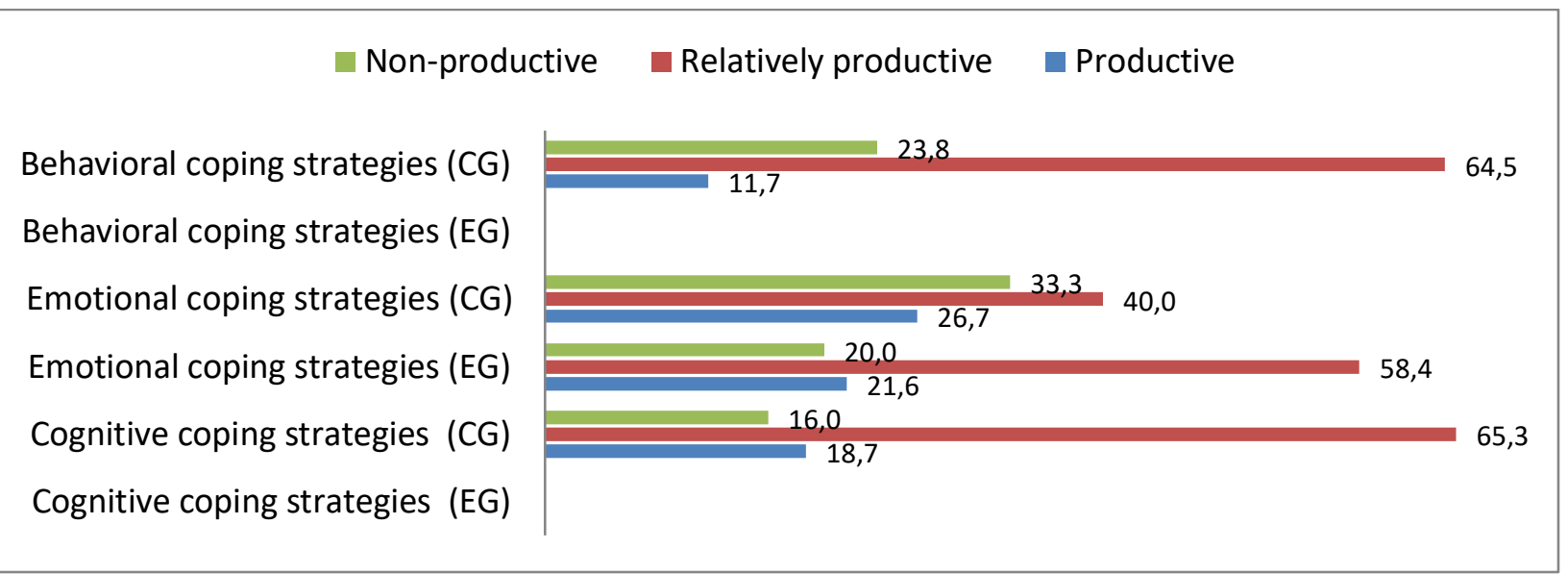

Figure 1. Students' coping strategies ( $E G$ and $C G)$. 
This includes analysis of the difficulties encountered, search for possible solutions to a similar situation, predicting dangers in the future.

The choice of different behaviour patterns in situations of risk depends on many factors. These are primary factors of social and psychological adaptation of young teachers and the burnout risk of experienced teachers. We also assume that insufficient teacher training with regard to the noxological competence plays a significant role in the issue of teachers' stress resilience.

\section{Analysis of the test results at the control stage}

All participants scored adequately on cognitive coping strategies (productive and relatively productive). Emotional and behavioural trajectories of stress management are represented by unproductive behaviour patterns. This suggests that it is necessary to introduce noxological component to teacher training curricula. The results of the coping strategies analysis are presented in Figures 1 and 2.

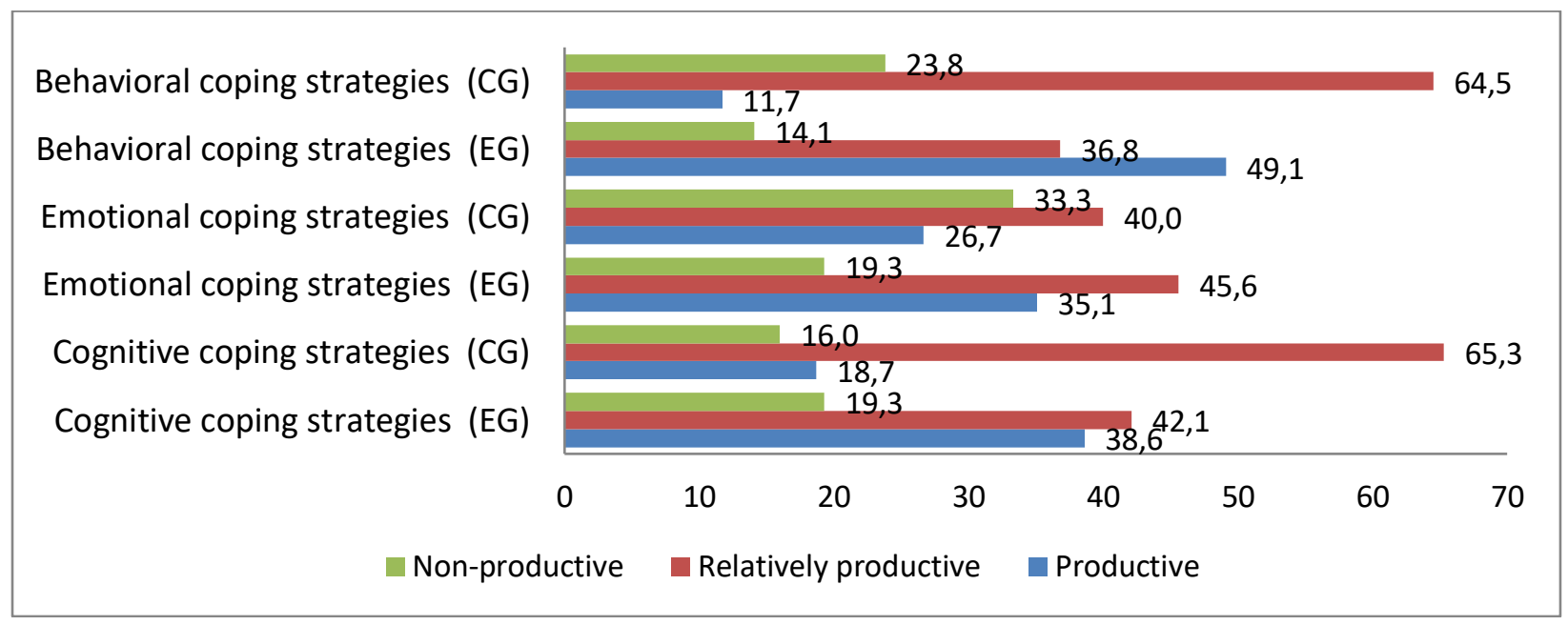

Figure 2. Comparative assessment of students' coping strategies in the control and experimental groups after the intervention.

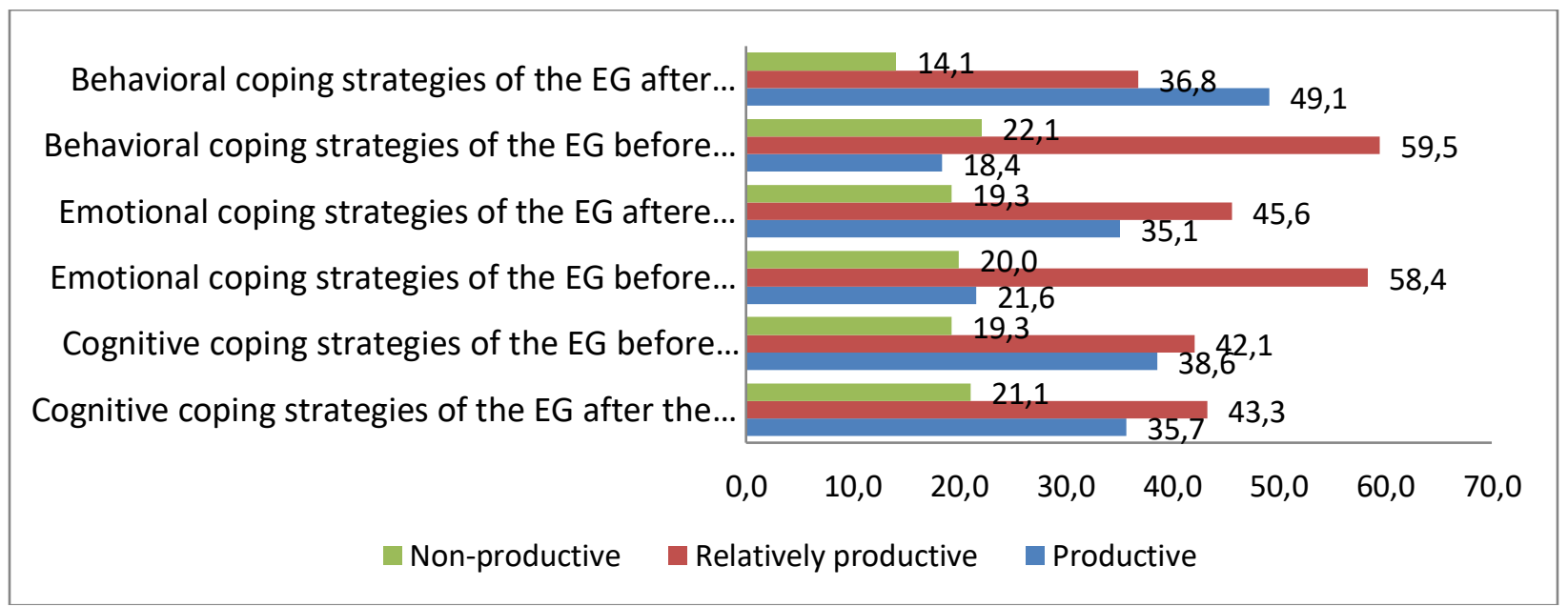

Figure 3. Comparative assessment of students' coping strategies in the control and experimental groups before and after the intervention. 


\section{The results based on the fisher's permutation test (f-test)}

The results of the Fisher's permutation test (F-test) in the experimental group at the ascertaining and control stages of the experiment are presented in Table 2.

Table 2. The results of the Fisher's permutation test on the coping strategies of the experimental group at the ascertaining and control stages of the experiment (significant differences).

\begin{tabular}{|c|c|c|c|}
\hline Forms of behaviour & Low & Average & High \\
\hline \multicolumn{4}{|l|}{ Cognitive coping strategies } \\
\hline P. Problem analysis & & & $3.175^{\star \star}$ \\
\hline O. Dissimilation & & $2.072^{\star *}$ & \\
\hline O. Disregard & $4.055^{\star *}$ & & \\
\hline O. Relativity & & 0.269 & \\
\hline O. Assigning a specific meaning & & $2.170^{*}$ & \\
\hline \multicolumn{4}{|l|}{0. Religiosity } \\
\hline O. Self-control & & 0.287 & \\
\hline O. Self-worth & & 1.208 & \\
\hline N. Perplexity & 0.179 & & \\
\hline N. Humility & 0.611 & & \\
\hline \multicolumn{4}{|l|}{ Emotional coping strategies } \\
\hline P. Optimism & & & 1.291 \\
\hline O. Protest & & 1.091 & \\
\hline O. Passive cooperation & & 0.077 & \\
\hline N. Aggressiveness & 0.998 & & \\
\hline N. Suppression of emotions & $3.358^{* *}$ & & \\
\hline N. Humility & 0.613 & & \\
\hline N. Self-condemnation & 0.246 & & \\
\hline N. Emotional discharge & 0.939 & & \\
\hline \multicolumn{4}{|l|}{ Behavioural coping strategies } \\
\hline P. Cooperation & & & $6.125^{\star \star}$ \\
\hline O. Distraction & $3.553^{* *}$ & & \\
\hline O. Constructive activity & & 0.298 & \\
\hline O. Appeal & & 1.045 & \\
\hline O. Altruism & & 0.783 & \\
\hline O. Compensation & & 0.422 & \\
\hline N. Active avoidance & 1.310 & & \\
\hline N. Retreat & 0.962 & & \\
\hline
\end{tabular}

Note: Table 2 contains significant differences at the significance level of $p \geq .05$ and $p \geq .01$.

The results of the experiment showed that there were significant changes in productive (problem analysis) and non-productive (dissimilation, disregard, assigning a specific meaning) coping strategies of students in the experimental group. Dissimilation coping strategies are defined as a deliberate intent to conceal or understate a given problem. The strategy of 'assigning a specific meaning' allows considering a difficult situation as a test, i.e., to reconcile with it and postpone actions necessary to confront the problem. In this case, the problem is perceived as a way of self-improvement. Increasing the significance of the problem analysis as the productive coping strategy and decreasing the significance of dissimilation, disregard, and 
assigning a specific meaning as the relatively productive coping strategy corresponds to the development of cognitive, analytical and reflexive components of the noxological competence.

There was also a decrease in the values of the 'emotional sublimation' strategy in emotional coping strategies of students from the experimental group. The results showed that student teachers are more inclined to use the 'emotional sublimation' strategy as the most appropriate for the teacher. The participants believed that teachers need to be able to avoid humiliation, conceal their emotions. At the same time, this strategy is a non-productive coping strategy that is manifested in depression, a state of hopelessness and humility, zero tolerance for other feelings, anger, blaming oneself and blaming others. These characteristics show the development level of situational and motivational components of the noxological competence of teachers.

Table 3. The results of the Fisher's permutation test on the coping strategies of the experimental and control groups at the control stages of the experiment.

\begin{tabular}{|c|c|c|c|}
\hline Forms of behaviour & Low & Average & High \\
\hline \multicolumn{4}{|l|}{ Cognitive coping strategies } \\
\hline P. Problem analysis & & & $2.73^{* *}$ \\
\hline O. Dissimilation & & $2.383^{* *}$ & \\
\hline \multicolumn{4}{|l|}{ O. Disregard } \\
\hline O. Relativity & & 0.73 & \\
\hline O. Assigning a specific meaning & & 1.041 & \\
\hline \multicolumn{4}{|l|}{ O. Religiosity } \\
\hline O. Self-control & & 0.543 & \\
\hline O. Self-worth & & 0.55 & \\
\hline N. Perplexity & 0.926 & & \\
\hline N. Humility & 0.424 & & \\
\hline \multicolumn{4}{|l|}{ Emotional coping strategies } \\
\hline P. Optimism & & & 0.844 \\
\hline O. Protest & & 1.562 & \\
\hline O. Passive cooperation & & 1.594 & \\
\hline N. Aggressiveness & 0.791 & & \\
\hline N. Suppression of emotions & 1.511 & & \\
\hline N. Humility & 0.04 & & \\
\hline N. Self-condemnation & 1.443 & & \\
\hline N. Emotional discharge & 0.304 & & \\
\hline \multicolumn{4}{|l|}{ Behavioural coping strategies } \\
\hline P. Cooperation & & & 1.421 \\
\hline \multicolumn{4}{|l|}{ O. Distraction } \\
\hline O. Constructive activity & & 0.113 & \\
\hline O. Appeal & & 0.063 & \\
\hline O. Altruism & & 0.739 & \\
\hline O. Compensation & & 0.057 & \\
\hline N. Active avoidance & 0.809 & & \\
\hline N. Retreat & 0.772 & & \\
\hline
\end{tabular}

Note: Table 3 contains significant differences at the significance level of $p \geq .05$ and $p \geq .01$. 
The analysis of behavioural coping strategies of the participants from the experimental group showed that the strategy 'cooperation', as a productive form of behaviour, scored higher and the strategy 'distraction', as a relatively productive form of behaviour, scored lower. Such tendencies indicate the development level of situational and behavioural components of the noxologic competence of the teacher.

Students from the experimental group used productive forms of behaviour (Table 2: problem analysis, optimism, cooperation) to analyse encountered difficulties and find ways out of them, increase self-esteem and self-control, have a deeper awareness of one's own value, resources to overcome difficult situations. The forms correspond to a high development level of the noxological competence.

Relatively productive forms of behaviour (Table 3: dissimilation, disregard, assigning a specific meaning, distraction) are used to evaluate and compare difficult situations, find a special meaning in challenges, grow spiritually. It is noteworthy that productive forms of behaviour in some situations can cause problems in other situations. That is why low scores on this group of strategies can be seen as a positive dynamic in the development of teachers' noxological competence. This is the characteristic of an average and high level noxological competence development which illustrates a conscious attitude to risks in professional activities.

The results of the Fisher's permutation test on the coping strategies of the experimental and control groups at the control stages of the experiment are presented in Table 3. We identified significant changes in cognitive coping strategies, for example, high scores of the experimental group regarding such forms of behaviour as 'problem analysis' and 'dissimilation'.

\section{CONCLUSION}

The noxologic competence has been disregarded in teacher training for a long time. Although the field of pedagogical riskology and noxology has been substantially theorized, it still lacks solid practical considerations. IN this research, we suggested a possible suitable measure to evaluate the effectiveness of the 'at-risk teacher training' model.

The research results showed that student teachers tend to resolve conflict situations as soon as possible. Students perceive conflicts as factors of risk which have a detrimental effect on students' well-being. At the same time, all participants underlined that conflict situations facilitate a better understanding of relationship patterns and laws and resolve problems, which is why conflicts should be a part of teaching and learning.

The research helped to identify student teachers' motivation for communication, behaviour patterns in conflict situations, ability to understand non-verbal communication cues and gestures, which are referred to as essential professional teaching competencies needed to resolve and manage conflict situations.

\section{Limitation and study forward}

This study was conducted only on students at Russian universities. While this research can be done globally to confirm the student teachers' motivation for communication, behaviour patterns in conflict situations, ability to understand non-verbal communication cues and gestures on other samples for more general results.

\section{ACKNOWLEDGMENTS}

The work is performed according to the Russian Government Program of Competitive Growth of Kazan Federal University. 


\section{REFERENCES}

Abramova, I.G. (1996). The theory of pedagogical risks. PhD Thesis, St. Petersburg.

Aronson, E., Wilson, T. D., \& Akert, R. M. (2015). Social Psychology (9th ed.). Boston, MA: Pearson/Allyn and Bacon.

Avdeev, V.A., Avdeeva, O.A., Shagieva, R.V., Smirnova,V.V., Mashkin, N.A., \& Taradonov, S.V. (2019). The mechanism of legal regulation in the conditions of globalization and formation of information environment. Regional aspect. Journal of Environmental Management and Tourism, 10(7), 1517152.

Bayanova, A.R., Vodenko, K.V., Sizova, Zh.M., Chistyakov, A.A., Prokopiev, A.I., \& Vasbieva, D.G. (2019). A philosophical view of organizational culture in contemporary universities. European Journal of Science and Theology, 15(3), 121-131.

Belov, S.V., \& Simakova, E.N. (2013). The New Direction of Scientific Knowledge - Nohsologiya. Part I. Theoretical Nohsologiya. Life safety, S8, 1-24.

Bespalko, V. P. (1996). Monitoring the quality of education: education management tool. World of Education, 2, 32-36.

Devisilov, V. A. (2011). Noxological aspects of education humanization. Higher education in Russia, 1, 129-132.

Duke, R.D., \& Duke, K.M. (1983). Chapter IX:a - Development of the Conrail game. Operational Gaming, 245-252. https://doi.org/10.1016/B978-0-08-030870-8.50026-6

Gimaliev, V.G., Prokopyev, A.I., Vershinin, V.P., Ivanova, M.E., Erkibaeva, G.G., Aytuganova, J.I., \& Alexandrova, N.S. (2020). Public Relations in Organizations in Student View: Accumulator of Management Tools or Formation of Partnership and Friendly Relations. Journal of environmental treatment techniques, 8(4), 1326-1330. https://doi.org/10.47277/JETT/8(4)1230

Havermans, N., Vanassche, S., \& Matthijs, K. (2017). Children's Post-Divorce Living Arrangements and School Engagement: Financial Resources, Parent-Child Relationship, Selectivity and Stress. Journal of Child and Family Studies, 26(12), 3425-3438. https://doi.org/10.1007/s10826-017-0843-0

Heim, E. (1988). Coping und Adaptivität: Gibt es geeignetes oder ungeeignetes Coping? Psychotherapie, Psychosomatik, Medizinische Psychologie, 38(1), 8-18.

Kayumova, L. R., \& Zakirova, V. G. (2016). Educational Environment Risks: Problems of Identification and Classification. International Journal of Environmental and Science Education, 11(6), 1013-1019. https://doi.org/10.12973/ijese.2016.370a

Kennedy, I. G., Latham, G., Jacinto, H. (2016). Education Skills for 21st Century Teachers. Voices From a Global Online Educators' Forum. 1st ed. SpringerBriefs in Education, $114 \mathrm{p}$. https://doi.org/10.1007/978-3-319-22608-8

Khairullina, E.R., Shubovich, M.M., Bogdanova, V.I., Slepneva, E.V., Mashkin, N.A., \& Rodyukova, T.N. (2020). Modern student youth civic identity: Political activity or social responsibility? Opcion, 36(Special Edition 27), 1703-1717.

Kong, Y., Kayumova, L. R., \& Zakirova, V. G. (2017). Simulation technologies in preparing teachers to deal with risks. EURASIA Journal of Mathematics, Science and Technology Education, 13(8), 47534763. https://doi.org/10.12973/eurasia.2017.00962a

Kutuev, R.A., Katicheva, M.G., Rassolov, I.M., Derdizova, F.V., Yevgrafova, O.G., \& Kozhanov, I.V. (2016). Practical recommendations on students' tolerant behavior formation in universities. International Journal of Environmental and Science Education, 11(17), 10365-10376.

Makarova, E.V., Kryukova, N.I., Sizova, Z.M., Grinenko, A.V., Erofeeva, M.A., and Bukalerova, L.A. (2019). Divergence of supreme values of Russian world and western civilization social and philosophical analysis. European Journal of Science and Theology, 15(3), 97-107. 
Middlewick, Y., Kettle, T. J., \& Wilson, J. J. (2012). Curtains up! Using forum theatre to rehearse the art of communication in healthcare education. Nurse education in practice, 12(3), 139-142. https://doi.org/10.1016/i.nepr.2011.10.010

Mikhailova, E. N. (2010). Pedagogical risks in research and experimental activities: forcasting and mitigation. World of science, culture, education, 3, 98-100.

Orekhovskaya NA, Chistyakov AA, Kryukova NI, Krokhina JA, Ospennikov YV, Makarova EV (2019) Orthodoxy and modernity their contact facets in Russian society. European Journal of Science and Theology, 15(2), 67-77.

Panfilova, A. P. (2006). Game-based modeling of the teacher's work: study guide for university students. Moscow: Academia.

Piralova, O.F., Gerasimenko, S.A., Kuznetsov, V.V., Popova, O.V., Subbotin, G.V., Kolomyts, O.G., \& Mashkin, N.A. (2020). Gaming Industry Trends in new Generation Specialist Training in University Environment. Journal of Environmental Treatment Techniques, 8(3), 1132-1135.

Plaksina, I. V. (2004). Interactive technologies in education. Vladimir.

Podymov, N.A., Nikoghosyan, M.A., Stolyarova, A.N., Narutto, S.V., Mashkin, N.A., Martynenko, S.E., Paznikova, Z.I., \& Varenik, P.K. (2019). University New Educational Reality in Disruptive Technologies Context. Journal of Environmental Treatment Techniques, 7(4), 664-668.

Prichinin, A. E. (2014) Organizational-methodological conditions for effective risk management in the context of an educational project. Bulletin of Udmurt University, 1, 78-84.

Prokofieva, E.N., Erdyneyeva, K.G., Galushkin, A.A., Prokopyev, A.I., Prasolov, V.I., Ashmarina, S.I., Ilkevich B., \& Kubiatko, M. (2018). Risk based ecological economics to engineering students. Eurasia Journal of Mathematics, Science and Technology Education, 14(3), 753-764. https://doi.org/10.12973/ejmste/80903

Razumovskaya, M.I., Larionova, A.A., Zaitseva, N.A., Petrina, O.A, Vinogradova, M.V., Nagay, N.G., Takhumova, O.V. (2019) Models of Integrated Interactions Organization in the Field of Environmental Education. Journal of Environmental Treatment Techniques (JETT),7(Issue 4): 576-580.

Sabinina, N. N. (2011). Risks in innovative activity of the teacher and their preventive maintenance. World of Science, Culture, Education, 6(1), 85-89.

Shinkevich, M.V., Mashkin, N.A., Ishmuradova, I.I., Kolosova, V.V., \& Popova, O.V. (2020). Management of sustainable consumption of energy resources in the conditions of digital transformation of the industrial complex. International Journal of Energy Economics and Policy, 10(5), 454-460. https://doi.org/10.32479/ijeep.10202

Zyubina, I.A., Dzyubenko, A.I., Borisenko, V.A., Popova, O.V., \& Prokopyev, A.I. (2019). Implicit Linguopragmatic strategies of speech behavior of English-speaking prosecutors. XLinguae, 12(4), 92-102. https://doi.org/10.18355/XL.2019.12.04.08

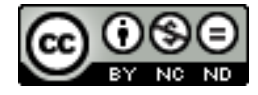

This work is licensed under a Attribution-NonCommercial-NoDerivatives 4.0 International (CC BY-NC-ND 4.0). 